\title{
PEMODELAN KECEPATAN ANGIN DI KOTA SEMARANG MENGGUNAKAN ADAPTIVE NEURO-FUZZY INFERENCE SYSTEM (ANFIS)
}

\author{
Alifah Zahlevi ${ }^{1}$, Alan Prahutama ${ }^{2}$, Abdul Hoyyi ${ }^{3}$ \\ ${ }^{1,2,3}$ Departemen Statistika FSM UNDIP \\ Alan.prahutama@gmail.com
}

\begin{abstract}
Semarang city is the one of the strategic areas located in the middle of the north coast of Java that has a tropical climate with the high humidity and temperature, so it often causes a high rainfall and strong wind. So that is way Semarang city is ever sustained the extreme weather like a Tropical Storm. Since January 2016 until 2017 there are 34 cases of Tornado and 24 incidents of fallen trees because of the gale. For helping the people to be allert the effect of the strong winds can be done by predicting the average of wind velocity by using Adaptive Neuro-Fuzzy Inference System (ANFIS) method which can predict the climate change that do not require the assumption of white noise and normal residual distribution. In addition ANFIS is a group of neural network with input that has been fuzzied on the first or second layer, but the weight of the artificial neural is not fuzzied. The identification result of stationaries obtained the plot of PACF on the first and second lag, with the result that these lag which will be a input variable on ANFIS model. The result of ANFIS by using cluster FCM, the third total membership show the smallest percentage of RMSE in-sample is 0,0048 on the first lag, and the smallest percentage of RMSE out-sample is 0,008 on the ANFIS model with the input lag 1 and three cluster.
\end{abstract}

Keywords : the average of wind velocity, ANFIS, RMSE

\section{PENDAHULUAN}

Kota Semarang berada di tengah-tengah pantai utara Jawa menjadikan kota Semarang beriklim tropis dengan suhu udara dan kelembaban udara yang tinggi, curah hujan yang tinggi dan disertai angin kencang (Badan Pusat Statistika atau BPS kota Semarang, 2009). Januari 2016, terdapat 34 kasus bencana puting beliung di wilayah Jawa Tengah dan 24 kejadian pohon tumbang yang disebabkan oleh angin kencang. Februari 2017, Badan Meteorologi dan Klimatologi Geofisika atau BMKG Semarang memperkirakan terjadi angin kencang disertai hujan di Jawa Tengah khususnya Semarang

Adaptive Neuro Fuzzy Inference System atau ANFIS merupakan salah satu model peramalan iklim yang digunakan oleh BMKG dimana metode ini tidak membutuhkan asumsi white noise dan residual berdistribusi normal dimana sering tidak ditemui pada data. ANFIS adalah salah satu sistem hybrid yang menggabungkan neural network dan fuzzy logic. Neuro fuzzy termasuk kelompok jaringan syaraf dengan input yang difuzzykan pada lapisan pertama atau kedua, namun bobot-bobot pada jaringan syaraf tiruan tersebut tidak difuzzykan. ANFIS menggunakan sistem inferensi fuzzy model Takagi Sugeno Kang (TSK) yang terdiri dari satu lapisan input, tiga lapisan tersembunyi, dan satu lapisan output.

Langkah dalam menganalisis dapat dimulai dengan menentukan variabel input yang akan digunakan dengan melihat lag pada plot PACF. Dari variabel input tersebut maka ditentukan jumlah keanggotaan dan fungsi keanggotaan. Berdasarkan variabel input diperoleh model terbaik. Dari variabel input terbaik maka ditentukan jumlah keanggotaan terbaik dengan mengganti jumlah keanggotaan. Model yang diperoleh dari hasil variabel input dan jumlah keanggotaan terbaik dapat digunakan untuk menentukan model terbaik berdasarkan fungsi keanggotaan. Dari keseluruhan model tersebut diperoleh nilai RSME dimana nilai RMSE ini yang akan digunakan untuk memperoleh model terbaik dengan melihat nilai RMSE terkecil. Model terbaik akan digunakan untuk meramalkan.

\section{TINJAUAN PUSTAKA}

\subsection{ANFIS}

Adaptive Neuro-Fuzzy Inference System (ANFIS) adalah salah satu sistem hybrid yang 
menggabungkan neural network dan fuzzy logic. ANFIS merupakan arsitektur yang secara fungsional sama dengan fuzzy rule based model Sugeno. (Kusumadewi \& Hartati, 2006). Pada arsitektur ANFIS digunakan dua aturan pada basis aturan model Sugeno (Jang, 1997) yaitu:

Rule I : If $\mathrm{x}_{1}$ is $\mathrm{A}_{1}$ and $\mathrm{x}_{2}$ is $\mathrm{B}_{1}$ Then $\mathrm{f}_{1}=\mathrm{c}_{11} \mathrm{x}_{1}+\mathrm{c}_{12} \mathrm{x}_{2}+\mathrm{c}_{10}$

Rule II : If $x_{1}$ is $A_{2}$ and $x_{2}$ is $B_{2}$ Then $f_{2}=c_{21} x_{1}+c_{22} x_{2}+c_{20}$

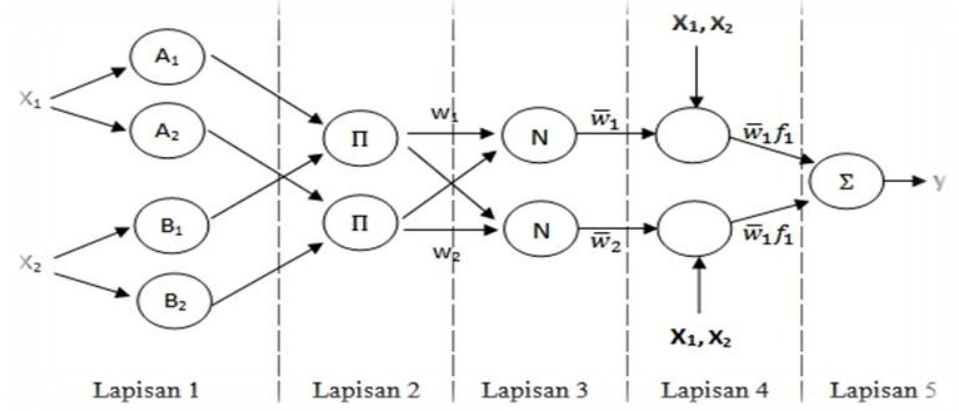

Gambar 1. Struktur ANFIS

Jaringan ANFIS terdiri dari lapisan-lapisan sebagai berikut (Jang, 1997):

a. Lapisan pertama berupa derajat keanggotaan yang diberikan oleh fungsi keanggotaan input. Fungsi keanggotaan yang digunakan adalah Gbell dimana $\{a, b, c\}$ adalah parameter-parameter, biasanya $b=1$. Parameter-parameter pada lapisan ini disebut dengan premise parameters.

$$
\mu(x)=\frac{1}{1+\left|\frac{x-c}{a}\right|^{2 b}}
$$

b. Lapisan kedua berupa neuron tetap yang outputnya adalah hasil dari masukkan. Tiaptiap node merepresentasikan predikat dari aturan ke-i. Lapsan ini disebut dengan firing strength.

$$
w_{i}=\mu_{A_{i}} \cdot \mu_{B_{i}}
$$

dimana $\mu_{A_{i}}$ adalah fungsi keanggotaan $A$ pada aturan ke- $i$ dan $\mu_{B_{i}}$ adalah fungsi keanggotaan $B$ pada aturan ke- $i$.

c. Lapisan ketiga disebut dengan normalised firing strength.

$$
\bar{w}_{i}=\frac{w_{i}}{w_{1}+w_{2}}
$$

d. Lapisan keempat, tiap-tiap neuron pada lapisan keempat merupakan node adaptif terhadap suatu output. $\bar{w}_{i}$ adalah normalised firing strength pada lapisan ketiga dan $\left\{c_{i 1}, c_{i 2}, c_{i 0}\right\}$ adalah parameter-parameter pada neuron tersebut. Parameter-parameter pada lapisan tersebut disebut dengan consequent parameters.

$$
\bar{w}_{i} y_{i}=\bar{w}_{i}\left(c_{i 1} x_{1}+c_{i 2} x_{2}+c_{i 0}\right)
$$

e. Lapisan kelima adalah node tetap yang merupakan jumlah dari semua masukan.

$$
O_{5, i}=\sum_{i} \bar{w}_{i} f_{i}=\frac{\sum_{i} w_{i} f_{i}}{\sum_{i} w_{i}}
$$

ANFIS dalam pengerjaannya menggunakan pembelajaran hybrid yang menggabungkan metode Least Square Estimator (LSE) dan error backpropagation (EBP). Pada langkah maju (forward), input jaringan akan merambat maju sampai pada lapisan keempat, dimana parameter-parameter $c_{i j}$ akan diidentifikasi dengan menggunakan metode LSE. Sedangkan pada langkah mundur (backward), error akan merambat mundur dan parameter-parameter $\left\{a_{i}, b_{i}, c_{i}\right\}$ akan diperbaiki dengan menggunakan metode gradientdescent. 


\subsection{Pemilihan Model Terbaik}

Salah satu cara untuk mengukur tingkat akurasi peramalan dapat dengan menggunakan RMSE atau Root Mean Square Error. RMSE merupakan nilai rata-rata dari jumlah kuadrat kesalahan, juga dapat menyatakan ukuran besarnya kesalahan yang dihasilkan oleh suatu model prakiraan. Nilai RMSE rendah menunjukkan bahwa variasi nilai yang dihasilkan oleh suatu model prakiraan mendekati variasi nilai obeservasinya (Makridakis dan Hibon, 1995).

\section{METODOLOGI PENELITIAN}

$$
R M S E=\sqrt{\frac{\sum_{i=1}^{m}\left(X_{i}-F_{i}\right)^{2}}{m}}=\sqrt{\frac{\sum_{i=1}^{m} e_{i}^{2}}{m}}
$$

\subsection{Sumber Data}

Sumber data untuk mendukung penelitian ini adalah data harian rata-rata kecepatan angin periode November 2016 sampai dengan April 2017 yang diperoleh dari laporan iklim harian yang terdapat pada website resmi BMKG yaitu dataonline.bmkg.go.id yang dibagi menjadi data in-sample dan data out-sample.

\subsection{Tahapan Analisis}

1. Menentukan plot PACF

2. Menentukan variabel input berdasarkan lag AR

3. Menenentukan jumlah keanggotaan. Fungsi keanggotaan (Membership Function) yang digunakan adalah Gbell, Gaussian, Triangle dan Trapezoidal serta banyaknya iterasi

4. Melakukan proses ANFIS berupa fuzzifikasi, operasi logika fuzzy, pengaktifan derajat ternormalisasi, dan defuzzifikasi

5. Meramalkan data out-sample dan menghitung RMSE data out-sample

6. Menentukan model terbaik berdasarkan RMSE terkecil.

\section{HASIL DAN PEMBAHASAN}

\subsection{Pemodelan ANFIS Berdasarkan Variabel Input dan Jumlah Keanggotaan 2}

Berdasarkan plot PACF pada Gambar 3, terlihat bahwa cut off setelah lag 2 sehingga variabel input yang digunakan untuk pemodelan ANFIS adalah lag 1 dan lag 2.

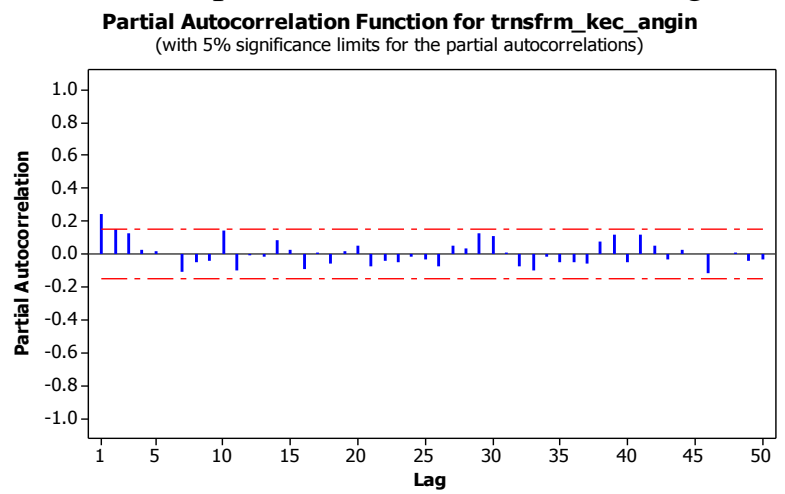

Gambar 3. Plot PACF Rata-rata Kecepatan Angin

Berdasarkan analisis ANFIS diperoleh model terbaik yaitu model ANFIS input lag 1 dengan nilai RMSE in-sample terkecil sebesar 0,004845 dan RMSE out-sample terkecil sebesar 0,008008, dengan persamaan sebagai berikut :

$$
\begin{aligned}
& \hat{y}_{t}^{(1)}=c_{11} y_{t-1}+c_{10} \\
& \hat{y}_{t}^{(2)}=c_{21} y_{t-1}+c_{20}
\end{aligned}
$$

Tabel 1. Nilai Awal Parameter Premis dengan input Lag 1 dengan 2 cluster 


\begin{tabular}{|c|c|}
\hline \multicolumn{2}{|c|}{ Input Lag 1} \\
\hline$a=0,3145$ & $a=0,449$ \\
\hline$b=2,001$ & $b=2,005$ \\
\hline $\mathrm{c}=0,4744$ & $\mathrm{c}=0,8283$ \\
\hline
\end{tabular}

Pada lapisan pertama diperoleh output berupa derajat keanggotaan pada tiap input. Parameter premis yang didapatkan melalui proses pembelajaran hibrid terdapat pada Tabel 1 sehingga fungsi Gbell yang terbentuk untuk mendapatkan derajat keanggotaan adalah :

$$
\begin{aligned}
& f_{11}\left(y_{t-1} ; a_{11} ; b_{11} ; c_{11}\right)=\frac{1}{1+\left|\frac{y_{t-1}-0,4744}{0,3145}\right|^{2(2,001)}} \\
& f_{21}\left(y_{t-1} ; a_{21} ; b_{21} ; c_{21}\right)=\frac{1}{1+\left|\frac{y_{t-1}-0,8283}{0,449}\right|^{2(2,005)}}
\end{aligned}
$$

Nilai derajat keanggotaan tersebut akan digunakan sebagai input pada lapisan kedua yang akan menghasilkan output berupa nilai $w_{i}$ sebanyak aturan yang terbentuk. Pada lapisan ketiga dilakukan normalisasi derajat pengaktifan aturan fuzzy atau disebut juga agregasi. Nilai $w_{i}$ pada lapisan kedua akan menjadi input sehingga diperoleh $\bar{w}_{i}$. Selanjutnya dilakukan proses defuzzifikasi pada lapisan keempat untuk mendapatkan parameter linear yaitu parameter konsekuen. Pada lapisan keempat hasil yang diperoleh berupa parameter konsekuen yang meminimumkan error. Parameter konsekuen hasil iterasi melalui algoritma pembelajaran adalah sebagai berikut :

$$
\begin{aligned}
& \hat{y}_{t}^{(1)}=-0,32 y_{t-1}-2,427 \\
& \hat{\boldsymbol{y}}_{\boldsymbol{t}}^{(\mathbf{2})}=\mathbf{- 7 , 2 1 5} \boldsymbol{y}_{\boldsymbol{t}-\mathbf{1}}+\mathbf{8}, \mathbf{3 2 4}
\end{aligned}
$$

Berdasarkan aturan yang terbentuk dari parameter konsekuen tersebut, maka model ramalan rata-rata kecepatan angin Stasiun Meteorologi Ahmad Yani yang diperoleh dengan menggunakan ANFIS dengan jumlah keanggotaan 2 adalah :

dimana,

$$
\hat{y}_{t}=\bar{w}_{1}\left(-0,32 y_{t-1}-2,427\right)+\bar{w}_{2}\left(-7,215 y_{t-1}+8,324\right)
$$

$$
\begin{aligned}
\bar{w}_{1}=\frac{w_{1}}{w_{1}+w_{2}}, \quad \bar{w}_{2} & =\frac{w_{2}}{w_{1}+w_{2}} \\
w_{1}=\frac{1}{1+\left|\frac{y_{t-1}-0,4744}{0,3145}\right|^{2(2,001)}}, \quad w_{2} & =\frac{1}{1+\left|\frac{y_{t-1}-0,8283}{0,449}\right|^{2(2,005)}}
\end{aligned}
$$

Sedangkan untuk model dengan variabel input lag 2 dan lag 1 dan 2 diperoleh nilai RMSE yang lebih besar dari nilai RMSE dengan variabel input lag 1 sebagai berikut :

Tabel 2. Nilai RMSE input Lag 1, Lag 2, Lag 1 dan 2 dengan 2 cluster

\begin{tabular}{|c|c|c|c|}
\hline RMSE & Lag 1 & Lag 2 & Lag 1 dan 2 \\
\hline In-sample & 0.004845 & 0.004883 & 0.004849 \\
\hline Out-sample & 0.008008 & 0.013482 & 0.014125 \\
\hline
\end{tabular}

\subsection{Pemodelan ANFIS Variabel Input Berdasarkan Jumlah Keanggotaan}

Berdasarkan analisis ANFIS diperoleh model terbaik yaitu model ANFIS input lag 1 dengan jumlah keanggotaan 3 dengan nilai RMSE in-sample terkecil sebesar 0,004831 dan RMSE out-sample terkecil sebesar 0,008001, dengan persamaan sebagai berikut :

$$
\hat{y}_{t}^{(1)}=c_{11} y_{t-1}+c_{10}
$$




$$
\begin{aligned}
& \hat{y}_{t}^{(2)}=c_{21} y_{t-1}+c_{20} \\
& \hat{y}_{t}^{(3)}=c_{31} y_{t-1}+c_{30}
\end{aligned}
$$

Tabel 3. Nilai Awal Parameter Premis dengan input Lag 1 dengan 3 cluster

\begin{tabular}{|c|c|c|}
\hline \multicolumn{3}{|c|}{ Input Lag 1 } \\
\hline$a=-0,02522$ & $a=0,1112$ & $a=0,1407$ \\
\hline$b=2,004$ & $b=2,005$ & $b=1,999$ \\
\hline $\mathrm{c}=0,3883$ & $\mathrm{c}=0,6996$ & $\mathrm{c}=1,002$ \\
\hline
\end{tabular}

Pada lapisan pertama diperoleh output berupa derajat keanggotaan pada tiap input. Parameter premis yang didapatkan melalui proses pembelajaran hibrid terdapat pada Tabel 3 sehingga fungsi Gbell yang terbentuk untuk mendapatkan derajat keanggotaan adalah :

$$
\begin{aligned}
& f_{11}\left(y_{t-1} ; a_{11} ; b_{11} ; c_{11}\right)=\frac{1}{1+\left|\frac{y_{t-1}-0,3883}{-0,02522}\right|^{2(2,004)}} \\
& f_{21}\left(y_{t-1} ; a_{21} ; b_{21} ; c_{21}\right)=\frac{1}{1+\left|\frac{y_{t-1}-0,6996}{0,1112}\right|^{2(2,005)}} \\
& f_{31}\left(y_{t-1} ; a_{31} ; b_{31} ; c_{31}\right)=\frac{1}{1+\left|\frac{y_{t-1}-1,002}{0,1407}\right|^{2(1,999)}}
\end{aligned}
$$

Nilai derajat keanggotaan tersebut akan digunakan sebagai input pada lapisan kedua yang akan menghasilkan output berupa nilai $w_{i}$ sebanyak aturan yang terbentuk. Pada lapisan ketiga dilakukan normalisasi derajat pengaktifan aturan fuzzy atau disebut juga agregasi. Nilai $w_{i}$ pada lapisan kedua akan menjadi input sehingga diperoleh $\bar{w}_{i}$. Selanjutnya dilakukan proses defuzzifikasi pada lapisan keempat untuk mendapatkan parameter linear yaitu parameter konsekuen. Pada lapisan keempat hasil yang diperoleh berupa parameter konsekuen yang meminimumkan error. Parameter konsekuen hasil iterasi melalui algoritma pembelajaran adalah sebagai berikut :

$$
\begin{gathered}
\hat{y}_{t}^{(1)}=0,1169 y_{t-1}+0,2591 \\
\hat{y}_{t}^{(2)}=0,1849 y_{t-1}+0,5309 \\
\hat{y}_{t}^{(3)}=0,3361 y_{t-1}-2,427
\end{gathered}
$$

Berdasarkan aturan yang terbentuk dari parameter konsekuen tersebut, maka model ramalan rata-rata kecepatan angin Stasiun Meteorologi Ahmad Yani yang diperoleh dengan menggunakan ANFIS dengan jumlah keanggotaan 2 adalah :

$\hat{y}_{t}=\bar{w}_{1}\left(0,1169 y_{t-1}+0,2591\right)+\bar{w}_{2}\left(0,1849 y_{t-1}+0,5309\right)+\bar{w}_{3}\left(0,3361 y_{t-1}-2,427\right)$ dimana,

$$
\begin{gathered}
\bar{w}_{1}=\frac{w_{1}}{w_{1}+w_{2}+w_{3}}, \quad \bar{w}_{2}=\frac{w_{2}}{w_{1}+w_{2}+w_{3}}, \quad \bar{w}_{3}=\frac{w_{3}}{w_{1}+w_{2}+w_{3}} \\
w_{1}=\frac{1}{1+\left|\frac{y_{t-1}-0,3883}{-0,02522}\right|^{2(2,004)}}, \quad w_{2}=\frac{1}{1+\left|\frac{y_{t-1}-0,6996}{0,1112}\right|^{2(2,005)}} \\
w_{3}=\frac{1}{1+\left|\frac{y_{t-1}-1,002}{0,1407}\right|^{2(1,999)}}
\end{gathered}
$$

\subsection{Pemodelan ANFIS Variabel Input dan Jumlah Keanggotaan 3 Berdasarkan Fungsi Keanggotaan}

4.3.1 Fungsi Gaussian 
Berdasarkan analisis ANFIS diperoleh model terbaik yaitu model ANFIS input lag 1 dengan jumlah keanggotaan 3 dengan nilai RMSE in-sample terkecil sebesar 0,004831 dan RMSE out-sample terkecil sebesar 0,008001, dengan persamaan sebagai berikut :

$$
\begin{aligned}
& \hat{y}_{t}^{(1)}=c_{11} y_{t-1}+c_{10} \\
& \hat{y}_{t}^{(2)}=c_{21} y_{t-1}+c_{20} \\
& \hat{y}_{t}^{(3)}=c_{31} y_{t-1}+c_{30}
\end{aligned}
$$

Tabel 4. Nilai Awal Parameter Premis dengan input Lag 1 dengan Jumlah Keanggotaan 3 dan Fungsi Keanggotaan Gaussian

\begin{tabular}{|c|c|c|}
\hline \multicolumn{3}{|c|}{ Input Lag 1} \\
\hline$\sigma_{11}=0,03159$ & $\sigma_{12}=0,06103$ & $\sigma_{13}=0,02617$ \\
\hline$\mu_{11}=0,5548$ & $\mu_{12}=0,6034$ & $\mu_{13}=0,7076$ \\
\hline
\end{tabular}

Pada lapisan pertama diperoleh output berupa derajat keanggotaan pada tiap input. Parameter premis yang didapatkan melalui proses pembelajaran hibrid terdapat pada Tabel 4 sehingga fungsi Gbell yang terbentuk untuk mendapatkan derajat keanggotaan adalah :

$$
\begin{aligned}
& f_{11}\left(y_{t-1} ; \sigma_{11} ; \mu_{11}\right)=\exp \left\{-\frac{1}{2}\left(\frac{\mathrm{y}_{\mathrm{t}-1}-0,5548}{0,03159}\right)^{2}\right\} \\
& f_{12}\left(y_{t-1} ; \sigma_{12} ; \mu_{12}\right)=\exp \left\{-\frac{1}{2}\left(\frac{\mathrm{y}_{\mathrm{t}-1}-0,6034}{0,06103}\right)^{2}\right\} \\
& f_{13}\left(y_{t-1} ; \sigma_{13} ; \mu_{13}\right)=\exp \left\{-\frac{1}{2}\left(\frac{\mathrm{y}_{\mathrm{t}-1}-0,7076}{0,02617}\right)^{2}\right\}
\end{aligned}
$$

Nilai derajat keanggotaan tersebut akan digunakan sebagai input pada lapisan kedua yang akan menghasilkan output berupa nilai $w_{i}$ sebanyak aturan yang terbentuk. Pada lapisan ketiga dilakukan normalisasi derajat pengaktifan aturan fuzzy atau disebut juga agregasi. Nilai $w_{i}$ pada lapisan kedua akan menjadi input sehingga diperoleh $\bar{w}_{i}$. Selanjutnya dilakukan proses defuzzifikasi pada lapisan keempat untuk mendapatkan parameter linear yaitu parameter konsekuen. Pada lapisan keempat hasil yang diperoleh berupa parameter konsekuen yang meminimumkan error. Parameter konsekuen hasil iterasi melalui algoritma pembelajaran adalah sebagai berikut :

$$
\begin{gathered}
\hat{y}_{t}^{(1)}=0,352 y_{t-1}+0,5763 \\
\hat{y}_{t}^{(2)}=0,4598 y_{t-1}+0,2473 \\
\hat{y}_{t}^{(3)}=0,3204 y_{t-1}+0,453
\end{gathered}
$$

Berdasarkan aturan yang terbentuk dari parameter konsekuen tersebut, maka model ramalan rata-rata kecepatan angin Stasiun Meteorologi Ahmad Yani yang diperoleh dengan menggunakan ANFIS dengan jumlah keanggotaan 2 adalah :

$$
\begin{gathered}
\hat{y}_{t}=\bar{w}_{1}\left(0,352 y_{t-1}+0,5763\right)+\bar{w}_{2}\left(0,4598 y_{t-1}+0,2473\right) \\
+\bar{w}_{3}\left(0,3204 y_{t-1}+0,453\right)
\end{gathered}
$$

dimana,

$$
\begin{gathered}
\bar{w}_{1}=\frac{w_{1}}{w_{1}+w_{2}+w_{3}}, \quad \bar{w}_{2}=\frac{w_{2}}{w_{1}+w_{2}+w_{3}}, \quad \bar{w}_{3}=\frac{w_{3}}{w_{1}+w_{2}+w_{3}} \\
w_{1}=\exp \left\{-\frac{1}{2}\left(\frac{\mathrm{y}_{\mathrm{t}-1}-0,5548}{0,03159}\right)^{2}\right\}, \quad w_{2}=\exp \left\{-\frac{1}{2}\left(\frac{\mathrm{y}_{\mathrm{t}-1}-0,6034}{0,06103}\right)^{2}\right\} \\
w_{3}=\exp \left\{-\frac{1}{2}\left(\frac{\mathrm{y}_{\mathrm{t}-1}-0,7076}{0,02617}\right)^{2}\right\}
\end{gathered}
$$




\subsubsection{Fungsi Triangular}

Berdasarkan analisis ANFIS diperoleh model terbaik yaitu model ANFIS input lag 1 dengan jumlah keanggotaan 3 dengan nilai RMSE in-sample terkecil sebesar 0,004831 dan RMSE out-sample terkecil sebesar 0,008001, dengan persamaan sebagai berikut :

$$
\begin{aligned}
& \hat{y}_{t}^{(1)}=c_{11} y_{t-1}+c_{10} \\
& \hat{y}_{t}^{(2)}=c_{21} y_{t-1}+c_{20} \\
& \hat{y}_{t}^{(3)}=c_{31} y_{t-1}+c_{30}
\end{aligned}
$$

Tabel 5. Nilai Awal Parameter Premis dengan input Lag 1 dengan Jumlah Keanggotaan 3 dan Fungsi Keanggotaan Triangular

\begin{tabular}{|c|c|c|}
\hline & \multicolumn{3}{|c|}{ Input Lag 1} \\
\hline$a_{11}=0,1708$ & $a_{12}=0,5074$ & $a_{133}=0,7236$ \\
\hline$b_{11}=0,4219$ & $b_{12}=0,6218$ & $b_{13}=1$ \\
\hline$c_{11}=0,8156$ & $c_{12}=0,9953$ & $c_{13}=1,276$ \\
\hline
\end{tabular}

Pada lapisan pertama diperoleh output berupa derajat keanggotaan pada tiap input. Parameter premis yang didapatkan melalui proses pembelajaran hibrid terdapat pada Tabel 5 sehingga fungsi Gbell yang terbentuk untuk mendapatkan derajat keanggotaan adalah :

$$
\begin{gathered}
f_{11}\left(y_{t-1} ; a_{11} ; b_{11} ; c_{11}\right)=\max \left(\min \left(\frac{y_{t-1}-0,1708}{0,4219-0,1708}, \frac{0,8156-y_{t-1}}{0,8156-0,4219}\right), 0\right) \\
f_{12}\left(y_{t-1} ; a_{12} ; b_{12} ; c_{12}\right)=\max \left(\min \left(\frac{y_{t-1}-0,5074}{0,6218-0,5074}, \frac{0,9953-y_{t-1}}{0,9953-0,6218}\right), 0\right) \\
f_{13}\left(y_{t-1} ; a_{13} ; b_{13} ; c_{13}\right)=\max \left(\min \left(\frac{y_{t-1}-0,7236}{1-0,7236}, \frac{1,276-y_{t-1}}{1,276-1}\right), 0\right)
\end{gathered}
$$

Nilai derajat keanggotaan tersebut akan digunakan sebagai input pada lapisan kedua yang akan menghasilkan output berupa nilai $w_{i}$ sebanyak aturan yang terbentuk. Pada lapisan ketiga dilakukan normalisasi derajat pengaktifan aturan fuzzy atau disebut juga agregasi. Nilai $w_{i}$ pada lapisan kedua akan menjadi input sehingga diperoleh $\bar{w}_{i}$. Selanjutnya dilakukan proses defuzzifikasi pada lapisan keempat untuk mendapatkan parameter linear yaitu parameter konsekuen. Pada lapisan keempat hasil yang diperoleh berupa parameter konsekuen yang meminimumkan error. Parameter konsekuen hasil iterasi melalui algoritma pembelajaran adalah sebagai berikut :

$$
\begin{gathered}
\hat{y}_{t}^{(1)}=2,579 y_{t-1}-0,6798 \\
\hat{y}_{t}^{(2)}=0,1749 y_{t-1}+0,3622 \\
\hat{y}_{t}^{(3)}=0,3536 y_{t-1}+0,3536
\end{gathered}
$$

Berdasarkan aturan yang terbentuk dari parameter konsekuen tersebut, maka model ramalan rata-rata kecepatan angin Stasiun Meteorologi Ahmad Yani yang diperoleh dengan menggunakan ANFIS dengan jumlah keanggotaan 2 adalah :

$$
\begin{gathered}
\hat{y}_{t}=\bar{w}_{1}\left(2,579 y_{t-1}-0,6798\right)+\bar{w}_{2}\left(0,1749 y_{t-1}+0,3622\right) \\
+\bar{w}_{3}\left(0,3536 y_{t-1}+0,3536\right)
\end{gathered}
$$

dimana,

$$
\begin{gathered}
\bar{w}_{1}=\frac{w_{1}}{w_{1}+w_{2}+w_{3}}, \quad \bar{w}_{2}=\frac{w_{2}}{w_{1}+w_{2}+w_{3}}, \quad \bar{w}_{3}=\frac{w_{3}}{w_{1}+w_{2}+w_{3}} \\
w_{1}=\max \left(\min \left(\frac{y_{t-1}-0,1708}{0,4219-0,1708}, \frac{0,8156-y_{t-1}}{0,8156-0,4219}\right), 0\right) \\
w_{2}=\max \left(\min \left(\frac{y_{t-1}-0,5074}{0,6218-0,5074}, \frac{0,9953-y_{t-1}}{0,9953-0,6218}\right), 0\right)
\end{gathered}
$$




$$
w_{3}=\max \left(\min \left(\frac{y_{t-1}-0,7236}{1-0,7236}, \frac{1,276-y_{t-1}}{1,276-1}\right), 0\right)
$$

\subsubsection{Fungsi Trapezoidal}

Berdasarkan analisis ANFIS diperoleh model terbaik yaitu model ANFIS input lag 1 dengan jumlah keanggotaan 3 dengan nilai RMSE in-sample terkecil sebesar 0,004831 dan RMSE out-sample terkecil sebesar 0,008001, dengan persamaan sebagai berikut :

$$
\begin{aligned}
& \hat{y}_{t}^{(1)}=c_{11} y_{t-1}+c_{10} \\
& \hat{y}_{t}^{(2)}=c_{21} y_{t-1}+c_{20} \\
& \hat{y}_{t}^{(3)}=c_{31} y_{t-1}+c_{30}
\end{aligned}
$$

Tabel 6. Nilai Awal Parameter Premis dengan input Lag 1 dengan Jumlah Keanggotaan 3 dan Fungsi Keanggotaan Trapezoidal

\begin{tabular}{|c|c|c|}
\hline \multicolumn{3}{|c|}{ Input Lag } \\
\hline$a_{11}=0,2537$ & $a_{12}=0,5015$ & $a_{13}=0,8065$ \\
\hline$b_{11}=0,3643$ & $b_{12}=0,6051$ & $b_{13}=0,9171$ \\
\hline$c_{11}=0,4941$ & $c_{12}=0,8065$ & $c_{13}=1,083$ \\
\hline$d_{11}=0,5747$ & $d_{12}=0,9171$ & $d_{13}=1,193$ \\
\hline
\end{tabular}

Pada lapisan pertama diperoleh output berupa derajat keanggotaan pada tiap input. Parameter premis yang didapatkan melalui proses pembelajaran hibrid terdapat pada Tabel 6 sehingga fungsi Gbell yang terbentuk untuk mendapatkan derajat keanggotaan adalah :

$$
\begin{gathered}
f_{11}\left(y_{t-1} ; a_{11} ; b_{11} ; c_{11} ; d_{11}\right)=\max \left(\min \left(\frac{y_{t-1}-0,2537}{0,3643-0,2537}, 1, \frac{0,5747-y_{t-1}}{0,5747-0,4941}\right), 0\right) \\
f_{12}\left(y_{t-1} ; a_{12} ; b_{12} ; c_{12} ; d_{12}\right)=\max \left(\min \left(\frac{y_{t-1}-0,5015}{0,6051-0,5015}, 1, \frac{0,9171-y_{t-1}}{0,9171-0,8065}\right), 0\right) \\
f_{13}\left(y_{t-1} ; a_{13} ; b_{13} ; c_{13} ; d_{13}\right)=\max \left(\min \left(\frac{y_{t-1}-0,8065}{0,9171-0,8065}, 1, \frac{1,193-y_{t-1}}{1,193-1,083}\right), 0\right)
\end{gathered}
$$

Nilai derajat keanggotaan tersebut akan digunakan sebagai input pada lapisan kedua yang akan menghasilkan output berupa nilai $w_{i}$ sebanyak aturan yang terbentuk. Pada lapisan ketiga dilakukan normalisasi derajat pengaktifan aturan fuzzy atau disebut juga agregasi. Nilai $w_{i}$ pada lapisan kedua akan menjadi input sehingga diperoleh $\bar{w}_{i}$. Selanjutnya dilakukan proses defuzzifikasi pada lapisan keempat untuk mendapatkan parameter linear yaitu parameter konsekuen. Pada lapisan keempat hasil yang diperoleh berupa parameter konsekuen yang meminimumkan error. Parameter konsekuen hasil iterasi melalui algoritma pembelajaran adalah sebagai berikut :

$$
\begin{gathered}
\hat{y}_{t}^{(1)}=2,579 y_{t-1}-0,6798 \\
\hat{y}_{t}^{(2)}=0,1833 y_{t-1}+0,5295 \\
\hat{y}_{t}^{(3)}=0,3536 y_{t-1}+0,3536
\end{gathered}
$$

Berdasarkan aturan yang terbentuk dari parameter konsekuen tersebut, maka model ramalan rata-rata kecepatan angin Stasiun Meteorologi Ahmad Yani yang diperoleh dengan menggunakan ANFIS dengan jumlah keanggotaan 2 adalah :

$$
\begin{gathered}
\hat{y}_{t}=\bar{w}_{1}\left(2,579 y_{t-1}-0,6798\right)+\bar{w}_{2}\left(0,1833 y_{t-1}+0,5295\right) \\
+\bar{w}_{3}\left(0,3536 y_{t-1}+0,3536\right)
\end{gathered}
$$

dimana,

$$
\bar{w}_{1}=\frac{w_{1}}{w_{1}+w_{2}+w_{3}}, \quad \bar{w}_{2}=\frac{w_{2}}{w_{1}+w_{2}+w_{3}}, \quad \bar{w}_{3}=\frac{w_{3}}{w_{1}+w_{2}+w_{3}}
$$




$$
\begin{aligned}
w_{1} & =\max \left(\min \left(\frac{y_{t-1}-0,2537}{0,3643-0,2537}, 1, \frac{0,5747-y_{t-1}}{0,5747-0,4941}\right), 0\right) \\
w_{2} & =\max \left(\min \left(\frac{y_{t-1}-0,5015}{0,6051-0,5015}, 1, \frac{0,9171-y_{t-1}}{0,9171-0,8065}\right), 0\right) \\
w_{3} & =\max \left(\min \left(\frac{y_{t-1}-0,8065}{0,9171-0,8065}, 1, \frac{1,193-y_{t-1}}{1,193-1,083}\right), 0\right)
\end{aligned}
$$

\subsection{Ukuran Ketepatan Model}

Berdasarkan Tabel 7, terlihat bahwa nilai RMSE pada Lag 1 dengan jumlah keanggotaan 3 dan fungsi keanggotaan Gbell, Triangular, Trapezoidal dan Gaussian memiliki nilai RMSE yang sama sehingga model terbaik adalah model ANFIS dengan input Lag 1 dan jumlah keanggotaan 3.

Tabel 7. Nilai RMSE input Lag 1 dengan 3 cluster

\begin{tabular}{|c|c|c|c|c|}
\hline \multirow{2}{*}{ RMSE } & \multicolumn{4}{|c|}{ Lag 1 dengan jumlah keanggotaan 3 } \\
\cline { 2 - 5 } & Gbell & Gaussian & Triangular & Trapezoidal \\
\hline In-sample & 0.004831 & 0.004831 & 0.004831 & 0.004831 \\
\hline Out-sample & 0.008001 & 0.008001 & 0.008001 & 0.008001 \\
\hline
\end{tabular}

\section{KESIMPULAN}

Berdasarkan hasil analisis dan pembahasan dengan metode Adaptive Neuro-Fuzzy Inference System (ANFIS) secara keseluruhan dapat dismpulkan sebagai berikut:

1. Berdasarkan input lag diperoleh model ANFIS terbaik dengan variabel input lag 1 dengan jumlah keanggotaan 2 dan fungsi keanggotaan Gbell. Nilai RMSE in-sample dan out-sample terkecil sebesar 0.004845 dan 0.008008 .

2. Berdasarkan jumlah keanggotaan dan fungsi keanggotaan diperoleh model ANFIS terbaik dengan variabel input lag 1 dengan jumlah keanggotaan 3 dan fungsi keanggotaan Gaussian, Gbell, Triangular dan Trapezoidal. Nilai RMSE in-sample dan out-sample terkecil sebesar 0.004831 dan 0.008001 .

3. Dari hasil ramalan dengan menggunakan model ANFIS didapatkan rata-rata kecepatan angin yang cukup berbeda karena error yang di peroleh masih sangat besar. Hal ini menunjukkan bahwa peralaman rata-rata kecepatan angin harian di Kota Semarang dengan menggunakan metode ANFIS tidak terlalu bagus.

\section{DAFTAR PUSTAKA}

[BMKG] Badan Meteorologi Klimatologi Geofisika Kota Semarang. 2016. Informasi Cuaca Bandar Udara Ahmad Yani Semarang. Semarang : Stasiun Meteorologi Kelas II Ahmad Yani.

[BPS] Badan Pusat Statistika Kota Semarang. 2016. Kota Semarang dalam Angka Semarang Municipality in Figures 2016. Semarang : BPS Kota Semarang.

Jang, JSR., CT Sun, dan E Mizutani. 1997. Neuro-Fuzzy and Soft Computing : A Computational Approach to Learning and Machine Intelligence. London : PrenticeHall, Inc.

Kusumadewi, S., dan Hartati, S. 2006. Neuro Fuzzy : Integrasi Sistem Fuzzy \& Jaringan Syaraf. Yogyakarta : Graha Ilmu.

Makridakis, S., and Hibon, M. 1995. Evaluating Accuracy (or Error) Measure. INSEAD Working Paper. Vol. 9518. Hal 2-3.

Nasir, A.A. dan Koesmaryono. 1990. Pengantar Ilmu Iklim Untuk Peranian. Bogor : Pustaka Jaya. 